\title{
La Conferencia Episcopal Española: ¿HAY NECESIDAd de UNA NORMATIVA PARTICULAR SOBRE FUNDACIONES AUTÓNOMAS?
}

\section{Introducción}

En la Iglesia Católica existe una indudable tendencia a la constitución de fundaciones autónomas. En las distintas Diócesis, ante cualquier necesidad se discute cuál es la figura que mejor se adapta a la finalidad que se persigue, y últimamente de manera casi automática, se acaba constituyendo una fundación autónoma. En los Institutos de Vida Consagrada, ante la escasez de vocaciones religiosas y la necesidad de pervivencia del carisma y de sus obras apostólicas y caritativas, se aprecia también la necesidad de constituir fundaciones autónomas.

Cuando se conoce la práctica del mundo fundacional, se llega a la conclusión de que la normativa del Código de Derecho Canónico, respecto a las fundaciones autónomas, es insuficiente para dar respuesta a la problemática generada por estas personas jurídicas.

En la práctica, en demasiadas ocasiones, se desconoce la diferencia entre asociaciones y fundaciones; tampoco se distingue entre fundaciones civiles y canónicas, y tampoco entre fundaciones pías autónomas y no autónomas. Pero lo verdaderamente dramático es que este desconocimiento no acontece únicamente entre personas legas en derecho, sino que alcanza a los profesionales del derecho (Abogados, Notarios, Registradores,...) e incluso a integrantes de algunas Curias Diocesanas, con lo cual proliferan

\footnotetext{
${ }^{8}$ Catedrático de Derecho Eclesiástico del Estado, Universidad CEU-Cardenal Herrera de Valencia, beneyto@uch.ceu.es.
} 
situaciones irregulares en la constitución, en el funcionamiento, en el gobierno de estas personas jurídicas canónicas.

En el presente trabajo se intentará exponer brevemente la situación de estas fundaciones autónomas en las diócesis españolas y en la Conferencia Episcopal española; luego analizar desde la práctica la problemática existente en el régimen jurídico de las mismas; y finalmente se esbozarán algunas propuestas que podrían integrar esta normativa particular sobre las fundaciones autónomas.

\section{Situación de las fundaciones autónomas en España}

\subsection{Situación de las fundaciones autónomas en las diócesis españolas}

Ha de partirse en este punto del excelente trabajo del Profesor Miguel Campo", concretamente en su apartado "3.3. La actividad diocesana relativa a fundaciones pías autónomas".

De la lectura de los boletines oficiales de las diócesis españolas en el período comprendido entre el año 1983 y noviembre de 2014, se contabilizan 220 entradas $^{2}$, de las que se deduce actividad de unas 172 fundaciones, mientras que el Registro de Entidades Religiosas cuenta con la inscripción de 392 fundaciones canónicas. ${ }^{3}$

Lo primero que se desprende de estos números es o bien la inactividad de la mayoría de las fundaciones autónomas, o bien que éstas no guardan la legalidad vigente.

El artículo 5 del Real Decreto 142/1981, de 9 de enero, sobre organización y funcionamiento del Registro de Entidades Religiosas, establecía: "1. La modificación de las circunstancias reseñadas en el artículo 3 será comunicada al Ministerio de Justicia en la forma prevista en dicho artículo para las peticiones de inscripción".

Y el artículo 3 exponía como datos requeridos para la inscripción los siguientes:

“a) Denominación de la entidad, de tal modo que sea idónea para distinguirla de cualquier otra.

b) Domicilio.

${ }^{1}$ M. CAMPO IBÁÑEZ, Las fundaciones canónicas en España. Derecho particular diocesano y realidad social, Ius Canonicum, 2015, nr 55, s. 641-694.

2 Ídem, s. 678-690, que forman el anexo 2 (Fundaciones autónomas 2014-1983).

3 Ídem, s. 668. 
c) Fines religiosos con respeto de los límites establecidos en el artículo 3 de la Ley Orgánica 7/1980, de 5 de julio, de Libertad Religiosa, al ejercicio de los derechos dimanantes de la libertad religiosa.

d) Régimen de funcionamiento y Organismos representativos, con expresión de sus facultades y de los requisitos para su válida designación.

e) Potestativamente, la relación nominal de las personas que ostentan la representación legal de la entidad. La correspondiente certificación registral será prueba suficiente para acreditar dicha cualidad."

Con el nuevo Real Decreto 594/2015, de 3 de julio, por el que se regula el Registro de Entidades Religiosas ${ }^{4}$, tendrán acceso al Registro, de acuerdo con el procedimiento que se establece en este Real Decreto, los siguientes actos:

a) La fundación o establecimiento en España de la entidad religiosa.

b) Las modificaciones estatutarias.

c) La identidad de los titulares del órgano de representación de la entidad.

d) La incorporación o separación de las entidades a una federación.

e) La disolución de la entidad.

f) Los lugares de culto.

g) Los ministros de culto.

Cualesquiera otros actos que sean susceptibles de inscripción o anotación conforme a los Acuerdos entre el Estado español y las confesiones religiosas. ${ }^{5}$

Se puede observar fácilmente que 392 fundaciones canónicas inscritas en el Registro de Entidades Religiosas habrán de generar miles de entradas en el mismo Registro. En ningún caso podrá ocurrir lo que ha sucedido en estos 31 años (1983-2014) en que ha habido únicamente 220 entradas contabilizadas en los boletines oficiales de las diócesis españolas.

Con estos datos en 31 años, y admitiendo como premisa (que es mucho admitir) que todas estas entradas en los boletines han sido notificadas al Registro de Entidades Religiosas, ni siquiera ha habido una entrada por fundación inscrita en el Registro. Esto supone que muchas fundaciones nunca han comunicado nada al Registro, ni modificaciones estatutarias, ni identidad de los titulares de los órganos de gobierno, ni disolución de la entidad.

\footnotetext{
${ }^{4}$ Boletín Oficial del Estado número 183, de 1 de agosto de 2015,

${ }^{5}$ Artículo 3 del Real Decreto.
} 
Del anexo 2 del artículo del Profesor Miguel Campo ${ }^{6}$, se desprende que la inmensa mayoría de las publicaciones en los Boletines Oficiales de las Diócesis españolas son por modificación de estatutos o por nombramientos de miembros de los distintos patronatos y, en algunos supuestos, por decretos de erección de algunas fundaciones autónomas.

El profesor Campo advierte: "de todos modos, los números comentados no son tampoco un reflejo totalmente fiel de esta actividad, pues mientras que en algunas archidiócesis la actividad es muy notable, especialmente Barcelona y Valencia, en otras es muy reducida -especialmente notable es el caso de Madrid- o inexistente. Por lo que toca al número de fundaciones de las que podemos tener noticia por los boletines (cualquiera que sea el tipo de acto publicado), tenemos una sola fundación para Ávila, León, Getafe, Mallorca, Gerona, Palencia, Segovia o Almería. Dos para las diócesis de Málaga y Tortosa. En cuanto a las archidiócesis, tenemos registros de dos fundaciones en los arzobispados de Burgos, Granada, Madrid, Oviedo, Pamplona y Sevilla. Frente a estos modestos números, en Zaragoza y Tarragona se da noticia de ocho fundaciones, nueve en Toledo, veintinueve en Valencia y cuarenta y dos en Barcelona." 7

Por ejemplo, en la diócesis de Valencia, donde hay 29 entradas en los Boletines Oficiales del Arzobispado (desde 1983-2014), según el profesor Beneyto " "hay 26 fundaciones domiciliadas en la capital de Valencia. De éstas, dos se encuentran extinguidas o en proceso de extinción. Igualmente en la Diócesis de Valencia, pero domiciliadas en pueblos pertenecientes al territorio de la Diócesis, hay 25 Fundaciones. De éstas, 3 se encuentran sin actividad."

A partir de la entrada en vigor del Real Decreto 594/2015, de 3 de julio, por el que se regula el Registro de Entidades Religiosas, que según su Disposición final quinta ${ }^{9}$ fue el 1 de noviembre de 2015, todas las solicitudes de inscripción o anotación en el Registro, junto con la documentación que deba acompañarse, podrán presentarse en formato y con firma electrónicos, sin perjuicio de lo dispuesto en la disposición adicional tercera. En esta disposición se establece que, en el plazo de dos años desde la entrada

${ }^{6}$ M. CAMPO IBÁÑ̃Z, Las fundaciones canónicas en España..., s. 678-690.

7 Ídem, s. 669.

${ }^{8}$ R. BENEYTO BERENGUER, Tipología de las fundaciones pías autónomas en la diócesis de Valencia, (en:) R. BENEYTO BERENGUER (Director), Reflexión y perspectivas de futuro de las fundaciones autónomas, Thomson Reuters Aranzadi, Cizur Menor 2013, s. 55-63.

9 “Este Real Decreto entrará en vigor a los tres meses de su publicación en el Boletín Oficial del Estado". La publicación fue en el Boletín Oficial del Estado número 183, de 1 de agosto de 2015 . 
en vigor (o sea hasta el 1 de noviembre de 2017) se habilitarán los recursos necesarios para la gestión electrónica de los procedimientos administrativos regulados y que el Registro de Entidades Religiosas sustituirá la conservación material de documentación por su almacenamiento mediante medios electrónicos, dotados de suficientes garantías. ${ }^{10}$

Y lo que es más relevante para las entidades eclesiásticas, en el mismo plazo (hasta el 1 de noviembre de 2017), las entidades inscritas en el Registro de Entidades Eclesiásticas deberán, en su caso, actualizar su situación registral conforme a los procedimientos previstos en este Real Decreto, en particular, en lo que se refiere a la inscripción obligatoria de los representantes legales. ${ }^{11}$

Aunque el profesor Herrera Ceballos califica como "deseada y esperada" la reforma del Registro de Entidades Religiosas ${ }^{12}$, y resalta como fortalezas del mismo su exhaustividad lo que reforzará el principio de seguridad jurídica, tanto en lo formal como en lo material, y la posibilidad de su tramitación electrónica ${ }^{13}$, sin embargo sería preocupante, si persiguiendo casi obsesivamente la igualdad pero confundiéndola con la uniformidad, se regularán todas las entidades religiosas del mismo, sacrificando la especialidad y la autonomía de lo religioso, despreciando la personalidad jurídica internacional de la Santa Sede y entrando los responsables del Registro a "calificar" lo que se entiende por "religioso" o no a pesar de lo dispuesto en la famosa Sentencia del Tribunal Constitucional 46/2001.de 15 de octubre ${ }^{14}$. Además supone que la Administración estatal será conocedora inmediatamente de toda la vida de estas entidades eclesiásticas: denominación, fines, actividades, dotación, órganos de gobierno, reglas para la aplicación de sus rendimientos a los fines fundacionales, causas de extinción y destino de los bienes.

${ }^{10}$ Disposición Adicional Tercera del Real Decreto.

${ }^{11}$ Disposición Adicional Cuarta del Real Decreto.

12 E. HERRERA CEBALLOS, Hacia la construcción de un Registro fiel reflejo de la realidad. La reforma del Registro de Entidades Religiosas, "Revista General de Derecho Canónico y Eclesiástico del Estado" 2015, nr 39, s. 1.

13 Ídem, s. 33.

14 “En consecuencia, atendidos el contexto constitucional en que se inserta el Registro de Entidades Religiosas, y los efectos jurídicos que para las comunidades o grupos religiosos comporta la inscripción, hemos de concluir que, mediante dicha actividad de constatación, la Administración responsable de dicho instrumento, no se mueve en un ámbito de discrecionalidad que le apodere con un cierto margen de apreciación para acordar o no la inscripción solicitada, sino que su actuación en este extremo no puede sino calificarse como reglada, y así viene a corroborarlo el art. 4.2 del Reglamento..." (Fundamento Jurídico 8). 
La primera conclusión que puede extraerse de lo anterior es que las fundaciones autónomas de la Iglesia no han mantenido contacto permanente con el Registro de Entidades Religiosas. La situación parece que habrá de cambiar con la nueva regulación del Registro, operada en el 2015.

Lo más preocupante es que son escasas las disposiciones emanadas por los Obispos diocesanos de cara a regular la existencia de las fundaciones pías autónomas. ${ }^{15}$ Concluimos con el profesor Miguel Campo: “Quizás, en atención a las demandas existentes en la sociedad española, se eche de menos un esfuerzo por parte de las diócesis de cara a establecer unas normativas que ayuden a implementar de un modo más claro principios como transparencia, eficacia y eficiencia en la gestión de las fundaciones pías autónomas, lo cual quizá pudiese ser un acicate para la constitución de un mayor número de fundaciones y que de este modo el servicio apostólico que la Iglesia española puede prestar a través de las mismas se haga más visible al común de los fieles y de la sociedad española". ${ }^{16}$

\subsection{Situación de las fundaciones autónomas en la Conferencia Episcopal Española.}

Además del artículo, ya citado, del profesor Miguel Campo en su epígrafe "3.2. Actividad de la Conferencia Episcopal Española", es obligado referirse al brillante artículo del profesor Jorge Otaduy titulado: "Fundaciones canónicas privadas promovidas por institutos religiosos en los sectores de la educación y de la sanidad"17.

En los dos artículos se relata la cronología de las fundaciones erigidas por la Conferencia Episcopal Española desde 1992 hasta 2014.

Según el artículo 17 de los Estatutos de la Conferencia Episcopal Española ${ }^{18}$ : "Son atribuciones de la Asamblea Plenaria las siguientes: 14으, Re-

15 J. CAMPO IBÁÑ̃Z, Las fundaciones canónicas en España..., p. 670, quien destaca los nombramientos de un asesor jurídico de fundaciones benéficas en el Arzobispado de Madrid-Alcalá, mediante Decreto de 20 de septiembre de 1985, y de un Delegado Diocesano para las Fundaciones en el Arzobispado de Toledo, mediante Decreto de 19 de diciembre de 1992.

16 Ídem, p. 673.

17 J. OTADUY GUERÍN, Fundaciones canónicas privadas promovidas por Institutos Religiosas en los sectores de la educación y de la sanidad, "Ius canonicum" 2015, nr 55, p. 695-722.

18 Texto de los Estatutos aprobado por la XCII Asamblea Plenaria de la Conferencia Episcopal Española (24-28 de noviembre de 2008) y confirmado por Decreto de la Congregación de Obispos de 19 de diciembre de 2008 en http://www.conferenciaepiscopal.es/ estatutos-cee/ (2016. 02.12). 
conocer y erigir asociaciones de fieles, instituciones y otras entidades de ámbito nacional con fin piadoso, caritativo o apostólico; revisar, o en su caso, aprobar sus estatutos y conferir a las mismas personalidad jurídica, conforme al Derecho vigente".

La Conferencia Episcopal, en ejercicio de sus atribuciones, ha realizado los siguientes actos jurídicos, ordenados cronológicamente desde 1992 hasta la fecha ${ }^{19}$ :

1) En 1992, la LVI Asamblea Plenaria erige canónicamente en persona jurídica privada de la Iglesia Católica a la fundación Educación Católica, y aprueba sus Estatutos el 22 de mayo. ${ }^{20}$

2) En 2004, la LXXXIII Asamblea Plenaria aprobó un “Modelo de estatutos de fundaciones canónicas promovidas por Institutos de Vida Consagrada en el ámbito educativo". ${ }^{21}$

3) En 2010, la XCVI Asamblea Plenaria aprueba los “Criterios básicos para el régimen de fundaciones canónicas privadas constituidas por institutos religiosos y erigidas por la Conferencia Episcopal Española" del 26 de noviembre ${ }^{22}$.

4) En 2011, la XCVIII Asamblea Plenaria aprobó la "Escuela Viva" como fundación privada de ámbito nacional, y le confirió personalidad jurídica privada. La fundación, de carácter educativo, ha sido promovida por FERE_CECA. ${ }^{23}$

5) En 2012, la XCLIX Asamblea Plenaria de la Conferencia Episcopal Española aprobó las fundaciones "Fundación Educativa Escolapias", “Fundación Escolapias Montal" y "Fundació Escolàpies" como fundaciones privadas de ámbito nacional, y les confirió personalidad jurídica privada. ${ }^{24}$ Las fundaciones, de carácter educativo, han sido promovidas por el Instituto Religioso de las Madres Escolapias.

6) En 2012, la C Asamblea Plenaria de la Conferencia Episcopal Española aprobó la "Fundación educativa Franciscanas de Montpellier", promovida por la Congregación Franciscana del Espíritu Santo (Franciscanas de Montpellier), como Fundación privada de ámbito nacional, y le confirió personalidad jurídica privada. ${ }^{25}$

19 J. CAMPO IBÁÑNEZ, Las fundaciones canónicas en España..., p. 678-692.

20 Ídem, p. 689.

${ }^{21}$ Del 22 al 26 de noviembre de 2004. Boletín Oficial de la Conferencia Episcopal 74 (31 diciembre 2004).

${ }^{22}$ Boletín Oficial de la Conferencia Episcopal Española 86 (31 diciembre 2010), pp. 85-86.

${ }^{23}$ Boletín Oficial de la Conferencia Episcopal Española 88 (31 diciembre 2011), p. 88.

${ }^{24}$ Boletín Oficial de la Conferencia Episcopal Española 89 (30 junio 2012), p. 70.

${ }^{25}$ Boletín Oficial de la Conferencia Episcopal Española 90 (31 diciembre 2012), p. 183. 
7) En 2013, la C Asamblea Plenaria de la Conferencia Episcopal Española aprobó la "Fundación educativa ACI (Ancillae Cordis Iesu), promovida por la Congregación de Esclavas del Sagrado Corazón, como Fundación privada de ámbito nacional, y le confirió personalidad jurídica privada. ${ }^{26}$

8) En 2013, la CII Asamblea Plenaria de la Conferencia Episcopal Española aprobó los estatutos de la Fundación educativa del Sur "Santo Tomás de Aquino" y la erigió como fundación pía autónoma privada de ámbito nacional. ${ }^{27}$

9) En 2013, la CII Asamblea Plenaria de la Conferencia Episcopal Española aprobó los "Criterios básicos para el régimen de fundaciones canónicas privadas (socio-sanitarias, asistenciales y otras) constituidas por Institutos de la Vida Consagrada y Sociedades de Vida Apostólica y erigidas por la Conferencia Episcopal Española". ${ }^{28}$

10 En 2013, la CII Asamblea Plenaria de la Conferencia Episcopal Española aprobó el Reglamento del Consejo Episcopal de Fundaciones Canónicas. ${ }^{29}$

11) En 2014, la CIII Asamblea Plenaria de la Conferencia Episcopal Española aprobó los estatutos de la Fundación "Spínola", de ámbito educativo y la erigió como fundación pía autónoma privada de ámbito nacional.

Tras observar detenidamente esta cronología se extraen la conclusión de que la Conferencia Episcopal Española ha seguido un itinerario un tanto confuso al elaborar una normativa particular sobre fundaciones. Es más, no ha habido legislación particular hasta el 2013, en que se aprueba el Reglamento del Consejo Episcopal de Fundaciones Canónicas.

Parece ser que el Título "Reglamento del Consejo Episcopal de Fundaciones Canónicas" no corresponde a la realidad, porque en el artículo 1 se fija el ámbito de actuación de este nuevo órgano, que comprenderá "principalmente" (por lo tanto no exclusivamente) las fundaciones promovidas por los Institutos de Vida Consagrada y Sociedades de Vida Apostólica en los ámbitos educativo y socio-sanitario. ${ }^{30}$

${ }^{26}$ Boletín Oficial de la Conferencia Episcopal Española 92 (31 diciembre 2013), p 183.

${ }^{27}$ Boletín Oficial de la Conferencia Episcopal Española 92 (31 diciembre 2013), p. 159.

${ }^{28}$ Del 18 al 22 de noviembre de 2013. Boletín Oficial de la Conferencia Episcopal 92 (31 diciembre 2013) pp. 103-105.

${ }^{29}$ Del 18 al 22 de noviembre de 2013. Boletín Oficial de la Conferencia Episcopal 92 (31 diciembre 2013) pp. 155-156.

${ }^{30}$ J. CAMPO IBÁÑEZ, Las fundaciones canónicas en España...., p. 667. 
Es una lástima que el Reglamento no estuviera pensando en todas las "entidades de ámbito nacional con fin piadoso, caritativo o apostólico"31, y, en cambio, todo el Reglamento transluzca la regulación de las fundaciones promovidas por los Institutos de Vida Consagrada. ${ }^{32}$ Como se verá a lo largo del trabajo, es necesaria una especie de Protectorado para todas las fundaciones canónicas de ámbito nacional, tanto las promovidas por las distintas Diócesis, como por los Institutos de Vida Consagrada como por otras entidades de la Iglesia Católica. Es necesaria también una especie de Consejo de Fundaciones, en el que estén representados no sólo Obispos y representantes de la Conferencia Episcopal, sino también los Institutos de Vida Consagrada y Sociedades de Vida Apostólica, y todos ellos asistidos por las personas de reconocido prestigio y competencia en la materia.

La Conferencia Episcopal Española se enfrentó al problema de las fundaciones canónicas promovidas por los Institutos de Vida Consagrada y Sociedades de Vida Apostólica que no se encuentran capacitados para constituir directamente estas fundaciones, por no disponer de la potestad eclesiástica de régimen en el fuero externo. Como expresa el profesor Otaduy "los llamados institutos religiosos laicales -algunos masculinos y todos los femeninos- no son titulares de la potestad de régimen y no pueden crear por sí mismos las correspondientes fundaciones canónicas" ${ }^{\prime 33}$.

Estos Institutos, a diferencia de los institutos pontificios de Derecho Pontificio que sí pueden crear directamente fundaciones canónicas a tenor de los cánones $596.2^{34}$ y $134.1^{35}$, no son titulares de la potestad de régimen

${ }^{31}$ Artículo $17.14^{\circ}$ de los Estatutos de la Conferencia Episcopal Española.

${ }^{32}$ En el número 6 se establece como órgano auxiliar del Consejo Episcopal de Fundaciones, un Equipo de Asesores formado por ocho personas: el Secretario Técnico de la Conferencia Episcopal Española, el Vicesecretario para Asuntos Económicos, los Directores de los Secretariados de las Comisiones Episcopales de Vida Consagrada, de Enseñanza y Catequesis, y de Pastoral, el Secretario Técnico de la Junta Episcopal de Asuntos Jurídi$\cos , \mathrm{y}$, por períodos renovales de cuatro años un miembro designado por la Confederación Española de Religiosos (CONFER) y otro por la Federación Española de Religiosos de la Enseñanza -Confederación de Escuelas Católicas (FERE-CECA). Y en el artículo 8 se señala como el Consejo Episcopal sustituye a todos los efectos al Departamento para las fundaciones canónicas promovidas por Institutos de Vida Consagrada en el ámbito educativo de 2011.

${ }^{33}$ J. OTADUY GUERÍN, Fundaciones canónicas privadas..., p. 698.

34 "En los institutos religiosos clericales de derecho pontificio tienen además potestad eclesiástica de régimen, tanto para el fuero externo como para el interno".

35 "Por el nombre de Ordinario se entienden en Derecho, ...también quienes en ellas tienen potestad ejecutiva ordinaria, es decir los Vicarios generales y episcopales, así también respecto a sus miembros, los Superiores mayores de institutos religiosos clericales de derecho pontificio y de sociedades clericales de vida apostólica de derecho pontificio que tienen, al menos, potestad ejecutiva ordinaria". 
y no pueden constituir por sí mismas fundaciones canónicas, sino que han de contar con la intervención del Ordinario de lugar, que será la Conferencia Episcopal Española, si pretenden constituir una fundación autónoma de ámbito nacional. ${ }^{36}$

La Conferencia Episcopal Española vio como algunos institutos clericales de derecho pontificio constituyeron fundaciones de ámbito nacional, erigidas no por la propia Conferencia Episcopal sino por sus Superiores mayores. Así la Fundación Loyola ${ }^{37}$, erigida en 1998 por el Prepósito General de la Compañía de Jesús, la Fundación Domingo Lázaro ${ }^{38}$ constituida en en marzo de 2001 por los Marianistas y la Fundación Proyecto Don Bosco $^{39}$, erigida en agosto de 1998.

La Conferencia Episcopal Española aprobó los estatutos de la Fundación Educación Católica promovida por la Federación Española de Religiosos de la Enseñanza el 22 de mayo de 1992, una modificación de su artículo 2 (los fines) el 20 de noviembre de 1992, y una modificación de los artículos 8 (patronato), 9 (renovación de los patronos) y 17 (modificación de estatutos) el 19/23 de noviembre de 2001. La Fundación Educación Católica, según el artículo 4 de sus estatutos, es "persona jurídica privada de la Iglesia Católica, por concesión expresa de la Conferencia Episcopal Española" ${ }^{40}$.

Pero en la LXXXIII Asamblea Plenaria de la Conferencia Episcopal celebrada los días 23 al 26 de noviembre de 2004, se aprobó un "Modelo de estatutos de fundaciones canónicas promovidas por Institutos de Vida Consagrada en el ámbito educativo".

En este modelo se pretendía que todas las fundaciones canónicas de ámbito nacional promovidas por institutos de vida consagrada y sociedades de vida apostólica, que no dispusieren de la potestad eclesiástica de régimen en el fuero externo, fueran erigidas por la Conferencia Episcopal Española como personas jurídicas eclesiásticas públicas, como Fundaciones Pías Autónomas de naturaleza pública.

Esta obligación de que todas estas fundaciones hubieran de ser necesariamente de naturaleza pública, ahuyentó a algunos Institutos de Vida Consagrada y Sociedades de Vida Apostólica, que prefirieron constituir fundaciones civiles a partir de este Modelo del 2004. El profesor Otaduy

${ }^{36}$ J. OTADUY GUERÍN, Fundaciones canónicas privadas..., p. 698.

${ }^{37}$ www.fundacionloyola.es (2016. 02.12).

${ }^{38} \mathrm{http}: / /$ femdl.micolegio.es/ver_seccionFija.aspx?id=2 (2016. 02.12).

${ }^{39} \mathrm{http} / / /$ www.proyectodonbosco.com/Contenidos/4/1/Inicios (2016. 02.12).

$40 \mathrm{http}: / /$ fundacioneducacioncatolica.com/sites/fundacioneducacioncatolica.com/files/ pagina/2015/05/estatutosfec-nov.01.pdf (2016. 02.12). 
lo califica como "episodio sorprendente"41 pero no resalta que quizá este modelo del 2004 fue el motivo de esta tendencia, sin entrar a discutir si las decisiones fueron o no acertadas. Lo cierto es que se constituyeron la Fundación Educativa Santo Domingo ${ }^{42}$, en el año 2007, (a iniciativa de las Dominicas), la Fundación Educativa Francisco Coll ${ }^{43}$, en 2007 (a iniciativa de las Hermanas de la Anunciata) y la Fundación Educativa Doctrina Cristiana $^{44}$, en 2008 (a iniciativa de la Congregación Misioneras de la Doctrina Cristiana).

Lo mismo ocurrió con la Fundación de Religiosos para la Salud, que fue creada el 12 de noviembre de 2007 por la Asamblea General de la Federación Española de Religiosos Socio-sanitarios, como una fundación civil, al amparo de la Ley 50/2002 e inscrita en el Registro estatal de fundaciones asistenciales del Ministerio de Sanidad, Política Social e Igualdad, por Orden Ministerial de 3 de junio de $2008{ }^{45}$

Debería hacer pensar tanto a la Conferencia Episcopal Española como a los Institutos de Vida Consagrada la situación de estas fundaciones de ámbito nacional que prefirieron ser civiles a ser fundaciones autónomas públicas con una mayor dependencia de la Conferencia Episcopal. A la Conferencia Episcopal Española su persistencia y cerrazón en que fueran de naturaleza pública (cuando posteriormente han admitido la posibilidad de la naturaleza privada) y a los Institutos de Vida Consagrada, que prefieran ser de naturaleza civil, sujetas al Protectorado de la Administración civil, antes que ser de naturaleza pública, sujetas al Protectorado de la Conferencia Episcopal Española.

Lo cierto es que el 26 de noviembre de 2010, la XCVI Asamblea Plenaria de la Conferencia Episcopal Española aprueba los “Criterios básicos para el régimen de fundaciones canónicas privadas constituidas por institutos religiosos y erigidas por la Conferencia Episcopal Española", y a partir de ese momento vuelven a constituirse una serie de fundaciones autónomas privadas:

1) En 2011, la XCVIII Asamblea Plenaria aprobó la "Escuela Viva"46 como fundación privada de ámbito nacional, y le confirió personalidad jurídica privada. La fundación, de carácter educativo, ha sido promovida por FERE-CECA.

${ }^{41}$ J. OTADUY GUERÍN, Fundaciones canónicas privadas..., p. 699.

${ }^{42} \mathrm{http}: / /$ www.fesd.es/ (2016. 02.12).

${ }^{43} \mathrm{http}$ ://fundacioneducativafranciscocoll.es/fefc_conocenos.php (2016. 02.12).

${ }^{44} \mathrm{http}$ ://www.fundaciondoctrinacristiana.es/historia_de_la_fundacion.html (2016. 02.12).

${ }^{45} \mathrm{http}$ ://www.fundacionfrs.es/\#!/conocenos (2016. 02.12).

46 www.escuelaviva.org (2016. 02.12). 
2) En 2012, la XCLIX Asamblea Plenaria de la Conferencia Episcopal Española aprobó las fundaciones "Fundación Educativa Escolapias" ${ }^{47}$, "Fundación Escolapias Montal" ${ }^{48}$ y "Fundació Escolàpies" como fundaciones privadas de ámbito nacional, y les confirió personalidad jurídica privada. ${ }^{49}$ Las fundaciones, de carácter educativo, han sido promovidas por el Instituto Religioso de las Madres Escolapias.

3) En 2012, la C Asamblea Plenaria de la Conferencia Episcopal Española aprobó la "Fundación educativa Franciscanas de Montpellier", promovida por la Congregación Franciscana del Espíritu Santo (Franciscanas de Montpellier), como Fundación privada de ámbito nacional, y le confirió personalidad jurídica privada..$^{50}$

4) En 2013, la C Asamblea Plenaria de la Conferencia Episcopal Española aprobó la "Fundación educativa ACI (Ancillae Cordis Iesu), promovida por la Congregación de Esclavas del Sagrado Corazón, como Fundación privada de ámbito nacional, y le confirió personalidad jurídica privada. ${ }^{51}$

5) En 2013, la CII Asamblea Plenaria de la Conferencia Episcopal Española aprobó los estatutos de la Fundación educativa del Sur "Santo Tomás de Aquino" y la erigió como fundación pía autónoma privada de ámbito nacional.

El profesor Otaduy advertía en su trabajo que "los institutos de vida consagrada dedicados a actividades sanitarias, en cambio, no parece que se hayan dirigido hasta ahora a la Conferencia Episcopal solicitando la erección de fundaciones canónicas análogas a las constituidas en el sector educativo y se mantiene la naturaleza civil de la entidad constituida en $2007^{\prime \prime} 52$

En la CII Asamblea Plenaria del 18-21 de noviembre de 2013 la Conferencia Episcopal aprueba los "Criterios básicos para el régimen de fundaciones canónicas privadas (socio-sanitarias, asistenciales y otras) constituidas por institutos de vida consagrada y sociedades de vida apostólica y erigidas por la Conferencia Episcopal Española.

${ }^{47}$ http://www.fe-escolapias.org/la-fundacion/bienvenidos/ (2016. 02.12).

${ }^{48} \mathrm{http}: / /$ fundacionescolapiasmontal.org/ (2016. 02.12).

49 Boletín Oficial de la Conferencia Episcopal Española 89 (30 junio 2012), 70.

${ }^{50} \mathrm{http}: / / w w w . f e f m o n t . e s /(2016.02 .12)$.

${ }^{51} \mathrm{http} / / /$ fundacioneducativaaci.com/content/historia-de-la-fundaci\%C3\%B3n-educativa-aci (2016. 02.12) donde se expresa que fue constituida el 20 de diciembre de 2012 y en septiembre de 2013 entran a formar parte de ella los colegios que las Esclavas tienen en España;

${ }^{52}$ J. OTADUY GUERÍN, Fundaciones canónicas privadas..., p. 702. 
En 2013, en la misma CII Asamblea Plenaria de la Conferencia Episcopal Española se aprobó el Reglamento del Consejo Episcopal de Fundaciones Canónicas. ${ }^{53}$

En 2014, la CIII Asamblea Plenaria de la Conferencia Episcopal Española aprobó los estatutos de la Fundación "Spínola", de ámbito educativo y la erigió como fundación pía autónoma privada de ámbito nacional. ${ }^{54}$

Otra conclusión que se puede extraer es que las fundaciones autónomas promovidas por Institutos de Vida Consagrada que han de ser constituidas por la Conferencia Episcopal no desean ser personas jurídicas públicas, sino privadas. Esta circunstancia añade mayor complejidad porque no acaba de estar clara la diferencia entre fundaciones autónomas públicas y privadas.

Se comparte las consecuencias de la calificación de estas fundaciones como públicas o privadas expuestas por el profesor Otaduy ${ }^{55}$ : las fundaciones públicas actúan in nomine Ecclesiae y las privada actúan en nombre propio; los bienes de las fundaciones públicas son eclesiásticos y se rigen por las normas del libro V del Código de Derecho Canónico, y las privadas se rigen por sus estatutos; las fundaciones públicas se encuentran sujetas a la alta dirección de la autoridad eclesiástica y sus órganos de gobierno normalmente están asignados por la autoridad eclesiástica, mientras que las fundaciones privadas tienen mayor libertad para nombrar a sus órganos de gobierno y la vigilancia de la autoridad eclesiástica es mínima.

Pero como se verá más adelante, en la práctica esta distinción no es tan pacífica $^{56}$. No se puede decir tan alegremente que las fundaciones privadas

${ }^{53}$ Del 18 al 22 de noviembre de 2013. Boletín Oficial de la Conferencia Episcopal 92 (31 diciembre 2013) 155-156.

${ }^{54} \mathrm{http} / / /$ sagradocorazonlinares.com/index.php/component/content/article/1-ultimas-noticias/1918-la-congregacion-constituye-la-qfundacion-spinolaq.html (2016. 02.12). Fundación constituida por la Congregación de Esclavas del Divino Corazón.

${ }_{55}^{5}$ J. OTADUY GUERÍN, Fundaciones canónicas privadas..., p. 704.

56 Esta distinción ha sido introducida por el Código de Derecho Canónico de 1983. El canon 116 se trata de una absoluta novedad en la legislación canónica de 1983. El canon 116 expresa que son públicas las fundaciones constituidas por la autoridad eclesiástica competente para que, dentro de los límites que se les señalan, cumplan en nombre de la Iglesia, a tenor de las prescripciones del derecho, la misión que se les confía mirando al bien público. El Código de Derecho Canónico de 1983 no define la persona jurídica privada, sino que la caracteriza negativamente: "las demás personas jurídicas son privadas". Pero la distinción entre unas y otras no está suficientemente clarificada en el Código de 1983. Porque el fin de las personas jurídicas privadas ha de ser también congruente con la misión de la Iglesia, y ha de trascender el interés de los individuos que lo forman. No hay una enumeración taxativa de los fines que la autoridad eclesiástica reserve exclusivamente para los entes creados por ella. Sería más exacto decir que se diferencian no por los fines públicos 
actúan en nombre propio y no en el de la Iglesia, porque a las privadas también es la autoridad eclesiástica quien les otorga la personalidad jurídica canónica y aprueba sus estatutos ${ }^{57}, \mathrm{y}$, a la hora de la verdad, también es la autoridad eclesiástica la que está detrás, hasta el punto de que la Fundación privada puede también extinguirse por Decreto de la Conferencia Episcopal Española, motu proprio por graves razones, después de oír al Patronato y a la Entidad fundadora. La Iglesia, en definitiva, está comprometida por la actuación de sus personas jurídicas eclesiásticas.

Tampoco hay una gran diferencia en la práctica entre las fundaciones públicas y privadas, pues los bienes de las privadas se rigen por sus estatutos, $\mathrm{y}$, al ser éstos aprobados por la autoridad eclesiástica, en muchos de ellos se exige la necesidad de contar con las licencias pertinentes de la autoridad eclesiástica para la administración y enajenación de bienes.

En la práctica el control de la autoridad eclesiástica respecto a los órganos de gobierno de las privadas existe pues el Ordinario como ejecutor de las pías voluntades ${ }^{58}$ puede y debe vigilar también, mediante visita, que se cumplan las pías voluntades; y los demás ejecutores deben rendirle cuentas una vez cumplida su función. ${ }^{59}$

Sería preciso un mayor desarrollo legislativo de las fundaciones autónomas. Si se entiende que ese desarrollo pudiera venir de la mano del canon 1304.2 cuando dice: "El derecho particular determinará condiciones más específicas para la constitución y aceptación de fundaciones", tanto los Obispos como la Conferencia Episcopal podrían estar facultados para este desarrollo. Pero si únicamente se entendiera para las fundaciones no autónomas, entonces debería la legislación universal autorizar a la legislación particular para desarrollar la normativa sobre fundaciones autónomas, porque lo que es indudable es la insuficiencia de normativa al respecto. $Y$ lo que no tiene sentido ni es adecuado ni conveniente es que se acepte como supletoria la normativa civil al respecto.

Sigue presente la duda de en base a qué competencia la Conferencia Episcopal Española ha aprobado ese "Modelo de estatutos de fundaciones canónicas promovidas por Institutos de Vida Consagrada en el ámbito

o privados sino por el modo en que lo hacen: las personas jurídicas públicas in nomine Ecclesiae, y las privadas en nombre propio, bajo la responsabilidad de las personas físicas que la integran. La característica de ser constituida por la autoridad eclesiástica competente se verifica en todas las fundaciones autónomas y no sirve para distinguir unas de otras.

57 Artículo 117: “Ninguna corporación o fundación que desee conseguir personalidad jurídica puede obtenerla si sus estatutos no han sido aprobados por la autoridad competente".

${ }^{58}$ Código de Derecho Canónico de 1983, can. 1301.1.

${ }^{59}$ Código de Derecho Canónico de 1983, can. 1301.2. 
educativo" en 2004, esos "Criterios básicos para el régimen de fundaciones canónicas privadas constituidas por institutos religiosos y erigidas por la Conferencia Episcopal Española" en 2010, esos "Criterios básicos para el régimen de fundaciones canónicas privadas (socio-sanitarias, asistenciales y otras) constituidas por Institutos de la Vida Consagrada y Sociedades de Vida Apostólica y erigidas por la Conferencia Episcopal Española" en 2013, y el Reglamento del Consejo Episcopal de Fundaciones Canónicas en 2013.

Si la Conferencia Episcopal Española tiene competencia para aprobar Criterios básicos para el régimen de fundaciones canónicas privadas (educativas o socio-sanitarias o asistenciales) e incluso para aprobar un Reglamento del Consejo Episcopal de Fundaciones, la tendrá también para elaborar una normativa completa sobre las Fundaciones autónomas de ámbito nacional, no sólo cuando estas fundaciones son promovidas por institutos de vida consagrada, sino cuando se trate de fundaciones promovidas por la misma Conferencia Episcopal, por varias diócesis o por una diócesis pero con actividades en todo el territorio nacional e incluso internacional. Esta normativa deberá extenderse tanto a las fundaciones públicas como privadas.

\section{Descripción del régimen jurídico de algunas fundaciones au- tónomas públicas y privadas.}

\subsection{Denominación.}

Es sabido que ninguna fundación que desee conseguir personalidad jurídica podrá obtenerla si sus estatutos no han sido aprobados por la autoridad eclesiástica competente ${ }^{60}$, y al contemplarse en los estatutos la denominación de "fundación católica" la aprobación de éstos supone simultáneamente el consentimiento a la utilización del término "católica". Estas precauciones obedecen a una medida cautelar, ya que la fundación, al llamarse católica (hospital católico, residencia católica, universidad católica...) puede inducir a pensar que se trata de una fundación muy próxima y vinculada a la Iglesia institución y que ésta respalda en su totalidad las actuaciones de aquélla. Por consiguiente, lo lógico será que las funda-

${ }^{60}$ Código de Derecho Canónico de 1983, can. 117. 
ciones autónomas públicas sean las que utilicen más el término "católico" en sus denominaciones. ${ }^{61}$

En la práctica, en algunas fundaciones autónomas, se observa lo siguiente:

Una fundación denominada "Santuario-Convento de la Mare de Déu del Castell" de Agres se constituye como fundación autónoma privada (Diócesis de Valencia).

Una fundación denominada "Colegio de la Inmaculada Concepción" de Teulada se constituye como fundación con personalidad jurídica pública (Diócesis de Valencia).

Una fundación denominada "Nuestra Señora de Valvanera para el patrimonio cultural" es una fundación autónoma pública (Diócesis de Calahorra y la Calzada-Logroño).

Una fundación denominada "Iglesia Colegial del Divino Salvador" es una fundación autónoma pública (diócesis de Sevilla).

Una fundación denominada "Fundación de la Junta Constructora del Templo Expiatorio de la Sagrada Familia", creada en 1895 por el entonces Obispo de Barcelona Jaume Catalá, es una fundación autónoma privada.

Una fundación denominada "Osio de Córdoba" es una fundación autónoma de naturaleza pública.

Una fundación denominada "Pía fundación autónoma Sant Martí de Girona" es una fundación autónoma privada.

Una fundación denominada "Fundación Proyecto Don Bosco" es una fundación autónoma privada.

La fundación educativa ACI (EDUCACI) es una fundación autónoma privada.

\subsection{Personalidad jurídica y régimen jurídico. ${ }^{62}$}

La fundación autónoma, la pública o privada, primero ha de adquirir personalidad jurídica canónica mediante el decreto de erección canónica y la aprobación de sus estatutos por la Autoridad eclesiástica competente; y después adquirir la personalidad jurídica civil mediante la inscripción

${ }^{61}$ R. BENEYTO BERENGUER, Estatuto jurídico de las obras de la Iglesia como fundación civil", (en:) J. BOSCH, (editor), Cuestiones actuales de derecho canónico y derecho eclesiástico del Estado (Actas de las XXXIV Jornadas de Actualidad Canónica, organizadas por la Asociación Española de Canonistas en Madrid, 23-25 de abril de 2014), Dykinson, Madrid 2015, pp. 212-213.

${ }^{62}$ R. BENEYTO BERENGUER, Estatuto jurídico de las obras..., pp. 213-214. 
en el Registro de Entidades Religiosas ${ }^{63}$. La fundación autónoma podrá ser erigida canónicamente por el Romano Pontífice, por la Conferencia Episcopal, por los Obispos diocesanos, o por los Superiores Mayores de los Institutos Religiosos Clericales de Derecho Pontificio.

La fundación autónoma no queda sujeta a la legislación civil estatal o autonómica, ya que la Ley Orgánica de Libertad Religiosa de $1980^{64}$, en su artículo 6.2 remitía al ordenamiento jurídico general, y en 1984 se dictó el Real Decreto 589/1984, de 8 de febrero de fundaciones religiosas de la Iglesia Católica ${ }^{65}$, reafirmando lo establecido en el artículo V del Acuerdo sobre Asuntos Jurídicos de 3 de enero de 197966: “...se regirán por sus normas estatutarias". No puede olvidarse que el Acuerdo Jurídico tiene valor de Tratado Internacional ${ }^{67}$.

Así lo prevé la Disposición Adicional Segunda de la Ley 50/2002, cuando afirma que: "Lo dispuesto en esta Ley se entiende sin perjuicio de lo establecido en los acuerdos con la Iglesia Católica y en los acuerdos de cooperación suscritos por el Estado con las Iglesias, Confesiones y Comunidades Religiosas así como en las normas dictadas para su aplicación, para las fundaciones creadas o fomentadas por las mismas". ${ }^{68}$

${ }^{63}$ Ver el Real Decreto 594/2015, de 3 de julio, por el que se regula el Registro de Entidades Religiosas (Boletín Oficial del Estado número 183, de 1 de agosto de 2015), donde la Disposición Transitoria segunda dispone: “Las fundaciones religiosas de la Iglesia Católica seguirán rigiéndose por el Real Decreto 589/1984, de 8 de febrero, de Fundaciones de la Iglesia Católica, en tanto no se regulen con carácter general las fundaciones de las entidades religiosas. Hasta entonces el Registro mantendrá la Sección de Fundaciones prevista en dicho real decreto".

${ }^{64}$ Ley Orgánica 7/1980, de 5 de julio, de libertad religiosa (Boletín Oficial del Estado de 24 de julio de 1980).

${ }^{65}$ Boletín Oficial del Estado de 28 de marzo de 1984.

${ }_{66}$ Acuerdo entre El Estado español y la Santa Sede, sobre Asuntos Jurídicos, firmado el 3 de enero de 1979, ratificado el 4 de diciembre de 1979 y publicado en el Boletín Oficial del Estado número 300, de 15 de diciembre de 1979.

67 Sentencia del Tribunal Constitucional número 66/1982, de 12 de noviembre, que en su Fundamento Jurídico 5 afirma: "No podemos menos de constatar que este Acuerdo del Estado español y la Santa Sede tiene rango de tratado internacional, y, por tanto, como aprecia el Fiscal, se inserta en la clasificación del art. 94 de la Constitución Española, sin que, respecto a él se hayan, institucionalmente, denunciado estipulaciones contrarias a la propia Constitución ni procedido conforme al art. 95 de la misma y, una vez publicado oficialmente el tratado, forma parte del ordenamiento interno".

${ }^{68}$ Ver Leyes 24, 25 y 26 de 10 de noviembre de 1992, por las que se aprueban los Acuerdos o Convenios de Cooperación con la Federación de Entidades Religiosas Evangélicas de España (FEREDE), con la Federación de Comunidades Israelitas (FCI) y con la Comisión Islámica de España (CIE). 


\subsection{Finalidades. ${ }^{69}$}

En los estatutos de la fundación autónoma deben contenerse expresamente los fines al cumplimiento de los cuales va dirigida la fundación, así como las actividades para alcanzar esos fines. Aunque lo acertado sería exponer de forma concreta estas finalidades, atendiendo a la inseguridad producida por la tendencia de función calificadora del Registro de Entidades Religiosas (que entraba a valorar qué se entendía por religioso y por fines religiosos, reduciéndolos a lo estrictamente religioso o a lo exclusivamente religioso, dejando fuera de lo religioso el apostolado y la caridad, por entender que era más educativo o cultural y asistencial $)^{70}$, actualmente la postura más acertada es la de ajustarse a los fines contenidos en la Instrucción de la Comisión Permanente de la Conferencia Episcopal de 5 de febrero de $1999^{71}$.

Además la Sentencia del Tribunal Constitucional número 46/2001, de 15 de febrero, dictada en base al recurso de amparo 3083/96, promovido por la Iglesia de la Unificación y otros frente a las Sentencias de las Salas de lo Contencioso-Administrativo del Tribunal Supremo y de la Audiencia Nacional, que desestimaron su recurso contra la negativa del Ministerio de Justicia a su inscripción en el Registro de Entidades Religiosas, a pesar de ser una sentencia, quizá poco acertada, y prueba de ello son los votos particulares, establece en el fundamento jurídico 8 , que ha de concluirse que la Administración responsable del Registro de Entidades Religiosas no se mueve en un ámbito de discrecionalidad que le apodere con un cierto margen de apreciación para acordar o no la inscripción solicitada, sino que su actuación en este extremo no puede sino calificarse como reglada. Y por tanto (Fundamento Jurídico 10), la Administración no debe arrogarse la función de juzgar el componente religioso de las entidades solicitantes del acceso al Registro, sino que debe limitarse a constatar que, atendidos sus estatutos, objetivos y fines, no son entidades de las excluidas en el artículo 3.2 de la Ley orgánica de libertad religiosa.

${ }^{69}$ R BENEYTO BERENGUER, Estatuto jurídico de las obras..., pp. 214-216.

70 R. BENEYTO BERENGUER, Las fundaciones religiosas de la Iglesia Católica. Fundaciones pías autónomas, Madrid 2007, pp.76-82.

${ }^{71}$ Instrucción de la Comisión Permanente de la Conferencia Episcopal Española, sobre la inscripción de asociaciones y fundaciones de la Iglesia Católica en el Registro de Entidades Religiosas del Ministerio de Justicia (Boletín Oficial de la Conferencia Episcopal Española, 1999, nr 80, pp. 36-40). Ver también M.E. OLMOS ORTEGA, La instrucción de la Conferencia Episcopal Española sobre la inscripción de asociaciones y fundaciones de la Iglesia Católica en el Registro de Entidades Religiosas. Texto y comentario: "Revista Española de Derecho Canónico" 2000, nr 57, pp. 213-226. 
La cuestión principal es dilucidar qué fines de los concretados en la Instrucción merecen revestir la forma jurídica de "fundación autónoma pública" y qué fines la de "fundación autónoma privada".

No debe caerse en la tentación de considerar como fundación autónoma pública aquella que tenga por finalidad el culto y la sustentación del clero ("la formación "seminarios, centros de espiritualidad y de ciencias eclesiásticas" y sustentación "alojamiento, alimentos, asistencia" de los ministros de culto y auxiliares de centros eclesiásticos", y como fundación autónoma privada aquella que tenga por finalidad el apostolado (la enseñanza confesional) y la caridad (casas de asistencia, orfanatos, residencia de ancianos, atención a emigrantes, discapacitados, etc). Además porque el siguiente paso sería considerar únicamente como religioso, y por tanto merecedora de revestir la forma de fundación autónoma, a las fundaciones que tengan por finalidad el culto y el sostenimiento del clero, mientras que el resto de finalidades deberían revestir la forma jurídica de fundaciones civiles ${ }^{72}$

En este sentido ya el artículo 6.1.d) del Real Decreto 594/2015, de 15 de julio, por el que se regula el Registro de Entidades Religiosas, ya considera como fines religiosos "sus bases doctrinales, la ausencia de ánimo de lucro y sus actividades religiosas específicas representadas por el ejercicio y fomento del culto, el mantenimiento de lugares y objetos de culto, la predicación, la intervención social, la difusión de información religiosa, la formación y enseñanza religiosa y moral, la asistencia religiosa, la formación y sustento de ministros de culto, y otros análogos".

En la práctica, en algunas fundaciones autónomas, se observa lo siguiente:

La Fundación "Santuario-Convento de la Mare de Déu del Castell", fundación privada, tiene como fines: Promover el culto público a la Mare de Déu del Castell, coadyuvar en la organización de los actos litúrgicos y religiosos. ¿Acaso no debería ser una fundación autónoma pública?.

La Fundación "Colegio de la Inmaculada Concepción de Teulada”, pública, tiene como fines propios: 1) La formación religiosa y moral de los fieles, principalmente en la Parroquia de Teulada, por medio de catequesis, escuelas de Teología, institutos y centros de formación religiosa. 2) La práctica de la caridad evangélica al servicio de los estudiantes de Teulada más pobres y necesitados. ¿Debe ser pública o podría ser también privada?.

${ }^{72}$ Ya lo afirmaba en 1996, R. BENEYTO BERENGUER, Fundaciones sociales de la Iglesia Católica. Conflicto Iglesia-Estado, Valencia 1996, pp. 152-154. 
La Fundación Nuestra Señora de Valvanera para el patrimonio cultural, pública, se propone como un fin eminentemente religioso y espiritual: la difusión del mensaje cristiano y la promoción del culto divino a través de la conservación y difusión del patrimonio artístico y cultural de la Iglesia, así como la formación en este campo de cualesquiera personas vinculadas con la Iglesia Católica. Todo ello en la línea de la tradición más genuina de la Iglesia, en la que el arte religioso es concebido como expresión de fe y medio de evangelización y catequesis.

La Fundación de la Junta Constructora del Templo Expiatorio de la Sagrada Familia, privada, tiene por finalidad fundacional la administración de los presupuestos y la ejecución del proyecto de construcción de un templo dedicado a la Sagrada Familia, siguiendo fielmente las directrices iniciales de Antoni Gaudí. Desde 1992 también se encarga de la gestión de la Casa-Museo Gaudí en el Park Güell, casa en la que residió Gaudí entre 1906 y 1926.

La Fundación Iglesia Colegial del Divino Salvador, pública, según sus estatutos tiene afectado de modo duradero su patrimonio a la gestión y puesta en valor del templo del Divino Salvador de Sevilla, que está orientado hacia la pastoral, la práctica del culto por los fieles católicos, y a la conservación y divulgación de la cultura sacra a través del patrimonio histórico-artístico de la Iglesia y de la Archidiócesis de Sevilla.

La Fundación "Osio de Córdoba”, pública, tiene por finalidad promover en sus beneficiarios la enseñanza confesional, conforme a los principios y valores propios de la doctrina de la Iglesia Católica. ¿Acaso no podría ser privada esta fundación?.

Es sorprendente la Pía Fundació Autònoma Sant Martí de Girona, privada, que tiene por finalidades: a) Colaborar con la Diócesis de Girona y sus instituciones en el sagrado apostolado y la evangelización..b) Colaborar en la mejora de las condiciones de vida y ministerio de los sacerdotes...c) Colaborar en la conservación, mejora y adecuación de los edificios...

A tenor de lo dispuesto en el canon 116.1, difícil resulta el apreciar como correcta la constitución de esta fundación como persona jurídica privada cuando su único objeto es colaborar con finalidades que son eminentemente públicas, que miran al bien público de la Iglesia. Colaborar en el sagrado apostolado y evangelización, conforme a los planes pastorales y las directrices del Obispo, colaborar en la mejora de las condiciones de vida y ministerio de los sacerdotes que trabajan en la Diócesis, y colaborar en la conservación, mejora y adecuación de los edificios destinados a dichas finalidades, difícilmente pueden apreciarse como fines de una 
persona jurídica privada. Pero también el problema se encuentra en qué se entiende por colaborar. No puede ser una finalidad de una persona jurídica únicamente la colaboración.

La Fundación Proyecto Don Bosco, privada, tiene por finalidad promover y desarrollar los valores educativos cristianos que vivió San Juan Bosco, en su experiencia pedagógica y espiritual...mediante la promoción personal, educativa y sociolaboral de menores y jóvenes, preferentemente aquellos que se encuentran en especial dificultad y colectivos en alto riesgo social y en situación de exclusión.

La Fundación Educativa ACI (EDUCACI), privada, tiene como fines promover en sus beneficiarios la educación y formación integral conforme a los valores evangélicos y la enseñanza confesional de acuerdo con los principios y valores propios de la doctrina de la Iglesia Católica y según el estilo educativo de la Entidad Fundadora recogido en sus documentos y tradiciones. Y reproduce casi literalmente el apartado correspondiente de la Instrucción de 5 de febrero de 1999. En definitiva es una fundación para la obra apostólica de formación y educación de las Provincias de España de la Congregación de las Esclavas del Sagrado Corazón de Jesús.

\subsection{Dotación.}

En Derecho Canónico se contempla también la necesidad de una dotación inicial ${ }^{73}$ hasta el punto de que la autoridad competente no conferirá personalidad jurídica sino a aquellas fundaciones, que, ponderadas todas las circunstancias, dispongan de medios que se prevé que pueden ser suficientes para alcanzar el fin que se proponen ${ }^{74}$. La dotación, pues, ha de ser suficiente y adecuada "según los usos del lugar o de la región"75.

Aunque el Código no establece una cantidad mínima para la dote, en virtud del canon 1304.2, el derecho particular podría establecerla como una condición para su constitución. Aunque el canon $1305^{76}$ está pensado más para las fundaciones no autónomas, el depósito y la colocación cuanto

${ }^{73}$ R. BENEYTO BERENGUER, Fundaciones sociales..., pp. 119-126.

${ }^{74}$ Código de Derecho Canónico de 1983, can. 114.3.

75 Código de Derecho Canónico de 1983, can. 1304.

76 "El dinero y los bienes muebles asignados como dote, han de depositarse inmediatamente en un lugar seguro aprobado por el Ordinario, a fin de conservar ese dinero o el precio de los bienes muebles, y colocarlo cuanto antes cauta y útilmente, en beneficio de la fundación, con mención expresa y detallada de las cargas, según el prudente juicio del Ordinario, oídos los interesados y su propio consejo de asuntos económicos". 
antes cauta y útilmente, no puede significar simplemente una gestión inmovilista de la dote para que no desaparezca, sino que debe administrarse "sin ánimo de lucro pero sí de beneficio, en forma de empresa", gestionándolo profesional y racionalmente, combinando la cautela y la seguridad con la utilidad y el máximo beneficio para la fundación.

La distinción entre las fundaciones autónomas públicas y privadas, respecto a la dotación, vendría concretada por el origen de esa dotación. ¿De dónde ha salido ese conjunto de bienes para merecer que la autoridad eclesiástica le confiera personalidad jurídica? ¿Sería válida la regla de que cuando los bienes de la dotación han salido del patrimonio de una persona jurídica eclesiástica pública la fundación autónoma ha de ser necesariamente pública, y cuándo salgan de personas jurídicas privadas o de personas físicas han de ser fundaciones autónomas privadas? O dicho de otra manera, al ser constituida la fundación autónoma privada a iniciativa de los fieles, la dotación ha de salir de los mismos fieles. En cambio, al ser constituida la fundación autónoma pública a iniciativa de la autoridad eclesiástica, la dotación ha de salir del patrimonio de personas jurídicas públicas.

Claramente se precisa una legislación particular sobre las fundaciones (en este caso de la dotación), bien de los distintos Obispos, bien de la Conferencia Episcopal Española, máxime cuando el canon 1304.2 establece que el derecho particular podrá establecer una cantidad mínima para la dote como una condición para su constitución. También porque muchos eclesiásticos y, por supuestos, laicos pretenden que la autoridad eclesiástica constituya con bienes eclesiásticos fundaciones autónomas privadas, en los que tanto la dotación como los órganos del gobierno de estas fundaciones estén sujetas a una vigilancia mínima de la autoridad eclesiástica.

En la práctica, en algunas fundaciones autónomas, se observa lo siguiente:

La Fundación "Santuario-Convento de la Mare de Déu de Agres" tiene como dotación 12.000 euros, que salen de la Parroquia donde está ubicado el Santuario-Convento, que a su vez es propiedad de la Diócesis, no de la Parroquia. En cualquier caso esa cantidad es un bien eclesiástico y pasa a ser la dotación de una persona jurídica privada.

La Fundación "Colegio de la Inmaculada Concepción de Teulada" se constituye con los bienes procedentes de la testamentaria del fundador. La Fundación es autónoma pública y afirman los estatutos que los bienes son eclesiásticos.

Según la web de la Fundación de la Junta Constructora del Templo Expiatorio de la Sagrada Familia, la dotación está formada por los donativos 
desinteresados y la recaudación procedente de la entrada donativo de los más de dos millones y medio de visitantes anuales que permiten la construcción. Esta fundación es autónoma privada.

La Fundación Iglesia Colegial del Divino Salvador, pública, tiene como dotación 35.000 euros, aportados por la Archidiócesis de Sevilla en un plazo de cinco años. Forma parte también de la dotación fundacional el derecho de uso del inmueble del templo del Divino Salvador, así como de los bienes muebles en él ubicados, propiedad de la Archidiócesis de Sevilla.

La Fundación "Osio de Córdoba", pública, tiene como dotación inicial 160.470 ' 23 euros. Y puede constituir también el patrimonio de la Fundación la titularidad de la escuela universitaria de Magisterio "Sagrado Corazón", de Córdoba.

La fundación Proyecto Don Bosco, privada, queda inicialmente dotada con los bienes que los fundadores dotan y aportan en el acto constitutivo, pero los fundadores son personas jurídicas públicas.

La Pía fundació autónoma Sant Martí de Girona, privada, tiene como dotación 500.000 euros, cuando su finalidad es simplemente de colaboración. Pero sigue diciendo en el artículo 7 de los estatutos: "Asimismo el Obispado podrá confiar a la Fundación la administración de las fincas que sean de su propiedad y no estén directamente destinadas al culto. Esta administración le será confiada de manera detallada y en documento fehaciente del Obispado de Girona. No obstante podrá incrementarse con otros bienes y derechos que la Fundación adquiera con este fin, por cualquier título". La cuestión es sí el Obispado puede confiar fincas que estén inscritas en el Registro de la Propiedad a nombre de una persona jurídica sujeta al Obispado, como por ejemplo de una parroquia. No puede hacerse sin que el Sr. Cura-Párroco lo diga.

\subsection{El Gobierno de la fundación.}

En la fundación civil deberá existir, con la denominación de Patronato, un órgano de gobierno y representación de la misma, al que corresponderá cumplir los fines fundacionales y administrar con diligencia los bienes y derechos que integran el patrimonio de la fundación. La labor de este Patronato, de alguna manera, siempre está supervisada y controlada por el Protectorado, por la Administración estatal o autonómica.

Lo mismo ocurre con las fundaciones autónomas, ya que en derecho canónico siempre ha habido una tendencia a considerar a las fundaciones como "menores" que necesitan protección y tutela, y a sus administra- 
dores y patronos como "negligentes y descuidados" (en el mejor de los casos), que precisan vigilancia y control. En el canon 1301, esa vigilancia y control viene atribuida al Ordinario, como ejecutor de las pías voluntades, especificando que puede y debe vigilar, mediante visita, que se cumplan éstas.

Los patronos pueden serlo atendiendo al cargo $\mathrm{u}$ oficio que desempeñan, por ejemplo, el Arzobispo, el Rector del Seminario, el Superior Provincial, el Alcalde, o atendiendo a sus cualidades personales. En este último supuesto, el cargo debe ejercerse personalmente, sin posibilidad de delegación. En el primer supuesto, nada obstaría a que, a pesar de que el cargo suele ser de confianza y honorífico, pudiera ser delegado en otras autoridades a tenor del canon 137. Si el cargo se ostenta en razón del oficio desempeñado, al ser sustituidos en ese oficio, lo serán también en el cargo de patrono. Por ejemplo, si el presidente de una fundación es el Arzobispo de Valencia, cuando éste sea sustituido por otro Arzobispo, será el nuevo quien ocupe la presidencia de la fundación. $\mathrm{O}$ si el cargo de patrono de una fundación es el Prior de una comunidad religiosa, cuando éste sea sustituido por otro Prior, será el nuevo quien ocupe el cargo de patrono.

¿Pueden ser patronos de una fundación autónoma las personas jurídicas, como una asociación, una cofradía, una Orden o Congregación Religiosa? Aunque en el canon 115.3 no queda muy clara esta posibilidad, sí parece poder admitirse cuando afirma "y es dirigida por una o varias personas físicas o por un colegio". Imaginando que determinadas corporaciones o fundaciones tomasen la iniciativa de originar una fundación, perfectamente cada una de estas entidades promotoras podrían ser patronos de la fundación a crear. En este caso, deberían estar representadas en el Patronato por una persona física.

Parece lógico que los miembros del patronato de una fundación autónoma pública sean autoridades eclesiásticas: Obispo, Vicario General, Vicarios Episcopales, Canciller-Secretario, Superior o Superiora Mayor de la Orden o Congregación Religiosa, etc. Igualmente parece lógico que los miembros del patronato de una fundación autónoma privada sean las mismas personas físicas o jurídicas que han tenido la iniciativa de dar origen a esa fundación y así lo han transmitido a la autoridad eclesiástica.

En la práctica, en algunas fundaciones autónomas, se observa lo siguiente:

En la Fundación "Santuario-Convento de la Mare de Déu de Agres", privada, el Patronato está integrado por: el Excmo. Sr. Arzobispo, el Presidente de la Diputación Provincial, el Sr. Alcalde de la localidad, el Párroco de la localidad, ....En una fundación privada el Presidente es el Arzobispo 
pero la mayoría de patronos son representantes del municipio. ¿Dónde está el problema? En que se necesita la restauración del santuario-convento, los fondos están en la Administración pública y no se quería una fundación religiosa sino civil. Luego se hizo un intermedio: una fundación religiosa privada.

En la Fundación "Colegio de la Inmaculada Concepción de Teulada", pública, el Patronato está integrado por miembros natos y electivos. Los natos son: El Arzobispo de Valencia, que será el Presidente, el Vicario Episcopal de la Vicaria correspondiente, el Párroco de la Parroquia de Teulada. Evidentemente es un patronato más acorde a una fundación pública, pero quizá sea un patronato con demasiadas autoridades eclesiásticas diocesanas o de ámbito supraparroquial para unos fines restrictivos a una localidad o parroquia.

En la Fundación Nuestra Señora de Valvanera para el patrimonio cultural, pública, el Patronato está integrado por cinco patronos natos y dos de libre designación por el Obispo. Los patronos natos son: El Obispo de Calahorra y la Calzada-Logroño, el Ecónomo Diocesano, el Delegado Diocesano para Patrimonio Cultural, el Delegado Diocesano del Servicio Litúrgico y el Director del Taller de Restauración (si lo hubiere).

En la Fundación de la Junta Constructora del Templo Expiatorio de la Sagrada Familia, privada, desde sus inicios y siguiendo la voluntad de los descendientes del fundador Josep M. Bocabella el presidente nato es el Arzobispo de Barcelona.

En la Fundación Iglesia Colegial del Divino Salvador, pública, el patronato está integrado por miembros natos y miembros designados. Son miembros natos: el Arzobispo de Sevilla, que ostenta la presidencia; el Vicario General de la Archidiócesis de Sevilla, y el Rector de la Iglesia Colegial del Divino Salvador de Sevilla.

En la Fundación "Osío de Córdoba”, pública, el patronato está integrado por un mínimo de ocho y un máximo de dieciséis miembros. Son miembros natos el Obispo diocesano y los Superiores Mayores de las otras entidades fundadoras. El resto de miembros será designado no por cada entidad fundadora por períodos de cuatro años renovables.

En la Fundación Proyecto Don Bosco, prívada, el Patronato está compuesto por diez patronos natos, a saber: El Inspector Provincial de la Inspectoría Salesiana, con sede en Sevilla, que actuará siempre como Presidente; cinco miembros de su Consejo Inspectorial, de entre ellos siempre el Vicario, el Ecónomo, y si pertenecieren al Consejo, el Delegado de Pastoral Juvenil, el Delegado de Formación y el Delegado de Familia Salesiana; los responsables de los tres grupos seglares de Familia Salesiana, y el Director General de la Fundación. 
En la Fundación Educativa ACI (EDUCACI), privada, el Patronato está integrado por un mínimo de cinco miembros y un máximo de once. Los patronos serán nombrados por la Entidad fundadora. Según el artículo 32, la entidad fundadora, que es la Congregación de las Esclavas del Sagrado Corazón de Jesús, tendrá la tutela sobre la orientación católica de la Fundación, y, a tal efecto, la dotará de carácter propio, designará a los patronos de la Fundación y tendrá la facultad de cesarlos; sin perjuicio de las competencias propias de la Conferencia Episcopal Española y del Ordinario del lugar, tendrá derecho de visita de todas las actividades de la Fundación, y una Superiora Mayor de la Congregación en España será responsable frente a la Conferencia Episcopal Española de la orientación católica de la fundación.

En la Pía Fundació Autònoma Sant Martí de Girona, privada, sorprende que se haya constituido esa fundación, como persona jurídica priva$\mathrm{da}$, para colaborar en unos fines que son claramente públicos, y teniendo como patronos de esa persona jurídica privada a un patronato integrado por el Vicario General de la Diócesis de Girona, por el Ecónomo diocesano, el Viceecónomo diocesano, y unos patronos nombrados por el Ordinario diocesano (artículo 18 de los Estatutos).

\subsection{Actos de disposición y enajenación del patrimonio.}

En las fundaciones civiles, el artículo 21 de la Ley 50/2002 dispone que la enajenación, onerosa o gratuita, así como el gravamen de los bienes y derechos que formen parte de la dotación, o estén directamente vinculados al cumplimiento de los fines fundacionales ${ }^{78}$, requerirán la previa autorización del Protectorado. Respecto de otros bienes cuyo importe sea superior al 20\% del activo de la fundación que resulte del último balance aprobado, su enajenación o gravamen debe ser comunicado por el Patronato a Protectorado en el plazo máximo de treinta días hábiles siguientes a su realización. La aceptación de legados con cargas o donaciones onerosas o remuneratorias y la repudiación de herencias, donaciones o legados

${ }_{77}$ Ley 50/2002, de 26 de diciembre, de Fundaciones (Boletín Oficial del Estado número 310, de 27 de diciembre de 2002).

${ }^{78}$ Cuando dicha vinculación esté contenida en una declaración de voluntad expresa, ya sea del fundador, del Patronato de la fundación o de la persona física o jurídica, pública o privada, que realice una aportación voluntaria a la fundación y siempre respecto de los bienes y derechos aportados. 
sin cargas serán comunicadas por el Patronato al Protectorado en el plazo de diez días hábiles ${ }^{79}$.

En las fundaciones autónomas, los administradores pueden perfectamente, en aras al deber de mejora de los bienes, realizar actos de disposición o enajenación de éstos para conseguir una mayor rentabilidad o una inversión distinta de la inicial, que permita un cumplimiento mejor de los fines fundacionales.

Los actos de enajenación de bienes ${ }^{80}$ de estas fundaciones deben sujetarse a las normas contenidas en los cánones 1290-1298:

-Los bienes de una fundación autónoma pública porque así lo dispone el c. 1257.1, al afirmar que los bienes que pertenecen a una persona jurídica pública son bienes eclesiásticos y se rigen por los cánones que siguen.

-Los bienes de una fundación autónoma privada por las siguientes razones: aunque el canon 1257.2 establezca que los bienes temporales de una persona jurídica privada se rigen por sus estatutos, el canon 1295 dispone que los estatutos de las personas jurídicas, sin distinguir entre las públicas y las privadas, se han de acomodar a los requisitos de los cánones. 1291$1294 .{ }^{81}$

Pero sobre todo, porque ¿Qué virtualidad tendría la vigilancia del Ordinario a que hace referencia el canon 1301.1 si los patronos pudieran enajenar los bienes de la fundación sin ningún control ni autorización?

Aunque el canon 1301.1 haga referencia a una vigilancia mediante visita, ésta no puede limitarse a un simple conocer, en su caso, la mala administración de los bienes cuando ésta ya se ha realizado. Además el "también" del canon 1301.1 denota que además de este medio, puede utilizar otros muchos para vigilar que se cumplan las pías voluntades: el más práctico de todos, que se incorpore a los estatutos la necesidad de observar los cánones 1291-1294 en la enajenación de los bienes. ${ }^{82}$

79 Artículo 22 de la Ley 50/2002.

80 Se entiende enajenación en sentido amplio tal como lo contempla el canon 1295 del Código de 1983: "Los requisitos establecidos en los cc. 1291-1294 a los que también se han de acomodar los estatutos de las personas jurídicas, deben observarse no sólo en las enajenaciones, sino también en cualquier operación de la que pueda resultar perjudicada la situación patrimonial de la persona jurídica".

${ }^{81}$ También se puede extraer esta conclusión de la "Acta Commisionis" en: "Communicationes" XII (1980), donde se modificó la expresión "situación patrimonial de la Iglesia" por "situación patrimonial de la persona jurídica".

82 A tenor de los cánones 1291-1292 y del Primer Decreto General de la Conferencia Episcopal Española de 26 de noviembre de 1983, para enajenar válidamente bienes de las fundaciones autónomas, deberá atenderse a las normas siguientes: a) Los bienes pertenecientes al patrimonio estable de las fundaciones, cuyo valor se halle entre los $150.000 \mathrm{y}$ 
En la práctica, en algunas fundaciones autónomas, se observa lo siguiente:

En la Fundación "Santuario-Convento de la Mare de Deú del Castell”, a pesar de ser una fundación autónoma privada, en los mismos Estatutos se contempla que corresponde al Obispo diocesano: El derecho de visita e inspección de las actividades de la fundación, la aprobación definitiva de las cuentas anuales, exigir al Patronato rendición de cuentas, y conceder la licencia necesaria para la enajenación de los bienes de la fundación, de acuerdo con las normas canónicas.

Igualmente se contempla en otro artículo de la misma fundación que si procediera en algún caso la enajenación de los bienes deberán observarse las normas del Código de Derecho Canónico sobre enajenación de bienes.

En la Fundación Nuestra Señora de Valvanera para el patrimonio cultural, pública, los bienes son eclesiásticos, y en los estatutos se contemplan como facultades del Obispo Diocesano las mismas que se han descrito en la fundación anterior.

1.500.000 euros, pueden ser enajenados con la licencia del Obispo Diocesano (con el consentimiento del Consejo de Asuntos Económicos y del Colegio de Consultores) o de la autoridad supradiocesana, si se trata de fundaciones no sujetas al Obispo diocesano; b) Los bienes pertenecientes al patrimonio estable de las fundaciones, cuyo valor es superior a 1.500.000 euros, pueden ser enajenados con la licencia de la Santa Sede (supuesta la licencia del Obispo diocesano con el consentimiento de los referidos consejos); c) Los bienes pertenecientes al patrimonio estable de las fundaciones, cuyo valor no alcanza los 150.000 euros, pueden ser enajenados sin ninguna licencia de la autoridad, aunque "si la cosa que va a enajenar es divisible, al pedir la licencia para la enajenación deben especificarse las partes anteriormente enajenadas, pues de lo contrario es inválida la licencia"; d) En uso de la facultad concedida por el canon 1297, la Conferencia Episcopal Española, a través del artículo 14.3 del Primer Decreto General de 26 de noviembre de 1983, estableció que el arrendamiento de bienes eclesiásticos, rústicos y urbanos, comprendidos en el canon 1297, se equipara a la enajenación en cuanto a los requisitos necesarios para su otorgamiento. El canon 1531.2 del Código de Derecho Canónico de 1917 dispuso que la enajenación se hiciera en pública subasta. Era un planteamiento normal de la época, que tenía por objeto asegurar que el bien no se enajenara por un precio menor al indicado en la tasación. Actualmente, y al haber desaparecido la subasta, estas precauciones se adoptan mediante las medidas dispuestas por el canon 1293: 1) Causa justa, como una necesidad urgente, una evidente utilidad, la piedad, la caridad y otra razón pastoral grave. 2) Tasación de la cosa que se va a enajenar, hecha por peritos y por escrito. El dictamen pericial permitirá apreciar el valor del bien que se quiere enajenar, y atendiendo a esta valoración, conocer las licencias que se deben obtener para la validez de la enajenación. Al mismo tiempo supone una garantía para la salvaguarda de los intereses de la fundación. 3) Otras cautelas prescritas por la legítima autoridad para evitar un daño a la Iglesia. 4) El dinero cobrado por la enajenación debe colocarse con cautela en beneficio de la fundación, o gastarse prudentemente conforme a los fines de dicha enajenación. 
En la Fundación Iglesia Colegial del Divino Salvador, pública, en el artículo 40 se dice: "A modo de protectorado, al Arzobispo y al Consejo Diocesano de Asuntos Económicos de la Archidiócesis de Sevilla les compete velar por el correcto ejercicio del derecho de fundación y por la legalidad de la constitución, funcionamiento y, en su caso, extinción de aquella". En el artículo 41.1 se dispone: "El Arzobispo, dadas las facultades de suprema vigilancia que le confieren los cc. 1276 y $1301 \mathrm{CIC}$, puede vetar los acuerdos del Patronato dejándolos sin efecto cuando estime que son contrarios a la moral católica, opuestos a este Estatuto, encontrados con los fines de la Fundación o gravemente perjudiciales para ésta", y finalmente en el artículo 42: "Corresponden al Consejo Diocesano de Asuntos Económicos de la Archidiócesis de Sevilla las siguientes funciones: a) Asesorar sobre cualquier cuestión relativa a las actividades realizadas por la Fundación en el cumplimiento de sus fines, prestándole a tal efecto el apoyo necesario. b) Velar por el efectivo cumplimiento de los fines fundacionales...c) Verificar si los recursos económicos de la Fundación han sido aplicados a los fines fundacionales...d) Ejercer provisionalmente las funciones del órgano de gobierno de la Fundación si por cualquier motivo faltasen todas las personas llamadas a integrarlo. e) Cuantas otras funciones se establezcan en este Estatuto". Quizás se hayan otorgado excesivas facultades al Consejo diocesano de asuntos económicos, a tenor de lo dispuesto en el canon 493 del Código de Derecho Canónico. Algunas de estas facultades lo son del Obispo diocesano.

En la Fundación "Osio de Córdoba", pública, los bienes son eclesiásticos y por tanto se rigen por lo dispuesto en el Derecho Canónico.

En la Fundación Proyecto Don Bosco, se dice que sin perjuicio de las normas canónicas generales o particulares, corresponde al Rector Mayor de la Congregación el derecho de visita e inspección de todas las obras y actividades educativo-pastorales de la Fundación. Asimismo se dispone en los estatutos que la administración de la fundación debe someterse a la aprobación del Rector Mayor de la Congregación.

En la Fundación Colegio de la Inmaculada Concepción de Teulada, fundación pública, los bienes son eclesiásticos, y la administración y enajenación de los bienes ha de sujetarse a las disposiciones relativas a los bienes eclesiásticos del Código de Derecho Canónico (cánones 1254 y siguientes) y demás disposiciones legales.

En la Fundación Educativa ACI (EDUCACI), a pesar de ser privada, se dice en el artículo 22: “Los actos de enajenación patrimonial se someterán a la licencia de la Santa Sede según la norma del Código de Derecho Canónico"; en el artículo 27 se dice que la Fundación presentará sus cuentas anuales a la Conferencia Episcopal española. 
En la Pía Fundació Autònoma de Sant Martí de Girona, fundación privada, sorprende, como se ha visto respecto a la dotación, que el Obispado pueda confiar a la Fundación la administración de una serie de fincas de su propiedad, y sorprende que el Obispado pueda confiar a una persona jurídica privada la administración de unos bienes que son eclesiásticos. Habría que precisar bien qué se entiende por administración, porque si de esa administración puede resultar perjudicada la situación patrimonial del Obispado, deberán recabarse las licencias y los consentimientos prescritos en los cc. 1291-1294 del Código de Derecho Canónico.

Con mucha más razón cuando no se trate de fincas de su propiedad, sino propiedad de otra persona jurídica eclesiástica pública, como una Parroquia. En este supuesto, deberá ser el párroco como representante legal de la Parroquia quien realice todos los trámites necesarios, contando también con el Consejo de Asuntos Económicos y con el Consejo Pastoral Parroquial.

A mayor abundancia, nos sorprende que la fundación tenga por finalidad el colaborar, y en cambio en el artículo 23 de los Estatutos se contenga una extensa enumeración de facultades, entre las que destaca el comprar, el vender, permutar, adquirir en leasing, ...; y en el artículo 24 se contenga la posibilidad de delegaciones y apoderamientos, y en los artículos 26 y 27 se contenga la existencia y las funciones de una Comisión Técnica Ejecutiva, y en el artículo 28, la existencia y funciones de un Director-Gerente.

\subsection{La modificación de estatutos y la fusión de fundaciones.}

En la fundación civil, a tenor de los artículos 29 y 30 de la Ley 50/2002, la modificación y la fusión con otras fundaciones deberán comunicarse al Protectorado, que podrá oponerse por razones de legalidad. Incluso el propio Protectorado podrá también requerir al Patronato para la modificación de estatutos o para la fusión, y si el Patronato se opone, podría solicitar de la autoridad judicial que resuelva sobre dicha modificación o fusión.

La modificación de estatutos, en la fundación autónoma, debe ser propuesta por el Patronato y presentada a la autoridad eclesiástica para su aprobación.

Nuestro Código de Derecho Canónico establece en el canon 121: “Si (...) las fundaciones que son personas jurídicas públicas se unen formando una sola totalidad con personalidad jurídica, esta nueva persona jurídica hace suyos los bienes y derechos patrimoniales propios de los anteriores y 
asume las cargas que pesaban sobre las mismas; pero deben quedar a salvo, sobre todo en cuanto al destino de los bienes y cumplimiento de las cargas, la voluntad de los fundadores y donantes, y los derechos adquiridos" y regula en el canon 122 la división de la persona jurídica pública con el reparto proporcional de derechos y bienes patrimoniales y demás cargas.

La fusión de fundaciones privadas no está contemplada en el Código y, por lo tanto, éstas gozan de libertad. Sin embargo, la autoridad eclesiástica ha de aprobar dicha fusión también cuando sean privadas y hayan sido erigidas canónicamente, puesto que si una fusión conlleva la supresión de las fusionadas para crear otra persona jurídica nueva, es claro que en derecho canónico únicamente pueden crear y suprimir personas jurídicas canónicas la autoridad eclesiástica, bien en virtud del mismo derecho, bien mediante decreto especial ${ }^{83}$.

En la Fundación Iglesia Colegial del Divino Salvador de Sevilla, pública, en el art. 43 se dice que para modificar los estatutos de la fundación deberá contarse también con la aprobación del Consejo Diocesano de Asuntos Económicos de la Archidiócesis de Sevilla. Sorprende este precepto, pues lo preceptivo es contar con la aprobación del Obispo diocesano y éste ya recabará los informes preceptivos.

En la Fundación "Osio de Córdoba”, la modificación de estatutos, la fusión y la extinción han de ser aprobadas por el Obispo diocesano.

En la Fundación Proyecto Don Bosco la modificación de estatutos debe ser aprobado por el Rector Mayor de la Congregación Salesiana.

En la Fundación Educativa ACI (EDUCACI) la adopción de acuerdos de modificación estatutaria, al igual que para la extinción, para su efectividad, requerirá la aprobación de la Entidad Fundadora, pero se presentará a ratificación de la Conferencia Episcopal Española.

\subsection{La extinción y el destino de los bienes en caso de extinción.}

La ley 50/2002, en su artículo 32 establece que la extinción de la fundación requerirá acuerdo del Patronato ratificado por el Protectorado. Si no hubiese acuerdo del Patronato, o éste no fuese ratificado por el Protectorado, la extinción de la fundación requerirá resolución judicial motivada.

La extinción de las fundaciones autónomas, si son públicas, se producirá por un acto de disposición de la autoridad eclesiástica competente,

${ }^{83}$ Código de Derecho Canónico de 1983, can. 116.2. 
o que tenga su raíz en la misma prescripción del derecho; si son privadas, por las mismas causas, pero añadiendo la pérdida de existencia según sus estatutos $^{84}$.

El procedimiento de liquidación en una fundación civil, según el artículo 33 de la Ley 50/2002, se realizará por el Patronato de la fundación bajo el control del Protectorado.

Los bienes y derechos resultantes de la liquidación se destinarán a las fundaciones o a las entidades no lucrativas que persigan fines de interés general y que tengan afectados sus bienes, incluso para el supuesto de su disolución, a la consecución de aquéllos, y que hayan sido designados en el negocio fundacional o en los Estatutos de la fundación extinguida. En su defecto, este destino podrá ser decidido, a favor de las mismas fundaciones y entidades mencionadas, por el Patronato, cuando tenga reconocida esa facultad por el fundador, $\mathrm{y}$, a falta de esa facultad, corresponderá al Protectorado cumplir ese cometido. Una excepción a esta regla viene establecida por el artículo 27.2 de la Ley 1/1998, de 2 de marzo, de Fundaciones de la Comunidad de Madrid que dispone: "A los bienes y derechos resultantes de la liquidación de una fundación extinguida se les dará el destino previsto por el fundador".

No obstante las fundaciones podrán prever en sus Estatutos o cláusulas fundacionales que los bienes y derechos resultantes de la liquidación sean destinados a entidades públicas, de naturaleza no fundacional, que persigan fines de interés general.

En derecho canónico, "cuando se extingue una persona jurídica pública, el destino de sus bienes y derechos patrimoniales, así como de sus cargas, se rige por el derecho y los estatutos; en caso del silencio de éstos, pasan a la persona jurídica inmediatamente superior, quedando siempre a salvo la voluntad de los fundadores o donantes, así como los derechos adquiridos; cuando se extingue una persona jurídica privada, el destino de sus bienes y cargas se rige por sus propios estatutos" ${ }^{\prime 85}$.

Los estatutos de las fundaciones, al hacer referencia al paso de sus bienes, en caso de extinción, a instituciones con finalidades análogas, deberían especificar que esas instituciones sean eclesiásticas y no civiles. Esta determinación es especialmente importante para las fundaciones públicas, cuyos bienes son eclesiásticos, ya que su pérdida supondría una disminución del patrimonio de la Iglesia.

\footnotetext{
${ }^{84}$ Código de Derecho Canónico, can. 120.1.

${ }^{85}$ Código de Derecho Canónico, can. 123.
} 
Por otra parte, el canon 117, mediante la previa aprobación de estatutos por la autoridad eclesiástica competente para conseguir la personalidad jurídica en la Iglesia, así como los cánones 1257 y siguientes para las fundaciones públicas, para el caso de bienes pertenecientes a fundaciones públicas, son una buena garantía de que el destino de los bienes, tanto de las fundaciones públicas como privadas, no supondrá una disminución del patrimonio de la Iglesia.

El destino de los bienes, cuando la extinción de las fundaciones haya venido motivada por una fusión o una división, deberá sujetarse a lo dispuesto en los cánones 121 y 122 del Código de 1983 y en los respectivos estatutos.

En la Fundación "Santuario-Convento de la Mare de Déu del Castell”, privada, se dice en sus estatutos que en caso de disolución de la fundación corresponde al Patronato proponer al Obispo Diocesano el destino de los bienes resultantes, el cual decidirá su atribución a obras o instituciones canónicas de finalidad análoga en la Parroquia de San Miguel de Agres". Pero téngase en cuenta que el bien es diocesano, el santuario es diocesano, y en cambio el destino de los bienes es para la Parroquia de la localidad.

En la Fundación Colegio Inmaculada Concepción de Teulada, pública, se dice en sus estatutos que en caso de extinguirse, el Patronato quedará constituido como Comisión Liquidadora, la cual una vez liquidados los bienes de la fundación, entregará el remanente al Arzobispo de Valencia para que lo destine a fines análogos o similares a los de la presente fundación.

En la Fundación Nuestra Señora de Valvanera para el patrimonio cultural, pública, se dice en sus estatutos que en caso de disolución de la fundación el patrimonio de ésta pasará a la Diócesis de Calahorra y la Calzada-Logroño.

En la Pía Fundació Autònoma Sant Martí de Girona, privada, se dice en el artículo 31: "En el caso de extinción de la Fundación, los bienes sobrantes, si los hubiese, serán destinados al Obispado de Girona".

PROPUESTAS PARA UNA NORMATIVA DE LA CONFEENCIA

EPISCOPAL SOBRE FUNDACIONES AUTÓNOMAS, PÚBLICAS

O PRIVADAS, DE ÁMBITO NACIONAL.

Primera.- Frente al hecho de que muchas fundaciones autónomas que gozan de una denominación como "Virgen de..." "San..." "Santa...", son fundaciones privadas, se propone que las fundaciones autónomas que 
sean privadas, en su denominación, no tengan términos que induzcan a pensar que la Jerarquía eclesiástica está allí presente. Esta terminología debería utilizarse únicamente en las fundaciones autónomas públicas. También podría ponerse en la denominación: "Fundación autónoma pública...", o "Fundación autónoma privada...".

Segunda.- Frente a la tentación y, a veces, realidad de únicamente constituir fundaciones autónomas públicas en aquellos supuestos en que éstas tengan como fines promover el culto público, la transmisión de la doctrina cristiana en nombre de la Iglesia ${ }^{86} \mathrm{y}$, en cambio, constituir como privadas las que tengan como fines el apostolado y la caridad, se propone que sea la autoridad eclesiástica la que resuelva claramente si la fundación a erigir ha de revestir la naturaleza de fundación autónoma pública o privada, ya que en definitiva es a ella a quien compete aprobar sus estatutos. En todo caso los fines reservados a la autoridad eclesiástica (que no se sabe bien cuáles son) deberán revestir necesariamente la forma de fundación autónoma pública.

Tercera.- Frente al hecho de que se erigen fundaciones privadas con bienes eclesiásticos, y se erigen fundaciones públicas con bienes cuyo origen está en el patrimonio de los fieles, se propone que cuando los bienes de la dotación hayan salido del patrimonio de una persona jurídica eclesiástica pública y, por tanto, sean bienes eclesiásticos, la fundación ha de ser necesariamente pública.

Cuarta.- En el gobierno de la fundación sí parece haber relación y, por tanto, se propone que los miembros del patronato de una fundación pública sean autoridades eclesiásticas, y que incluso puedan serlo de fundaciones privadas. Todo ello teniendo en cuenta que en las públicas, al actuar en nombre de la Iglesia, normalmente los patronos o, al menos los órganos unipersonales (Presidente, Vicepresidente, Secretario, Tesorero) serán autoridades eclesiásticas. ${ }^{87}$

Se propone que en las privadas, haya mayor libertad ya que puede estar formada por personas físicas y/o jurídicas privadas, sin necesidad de ser nombrados ni designados por la autoridad eclesiástica, ni mucho menos presididos por la misma autoridad eclesiástica. ${ }^{88}$

Quinta.- Respecto a los actos de disposición y enajenación del patrimonio en las fundaciones públicas se propone lo que es obligatorio: el

${ }^{86}$ Código de Derecho Canónico de 1983, can. 301.

87 Código de Derecho Canónico de 1983, can. 118 dispone: “Representan a la persona jurídica pública, actuando en su nombre, aquellos a quienes reconoce esta competencia el derecho universal o particular, o los propios estatutos".

${ }^{88}$ Código de Derecho Canónico de 1983, can. 118 dispone: “Representan a la persona jurídica privada aquéllos a quienes los estatutos atribuyen tal competencia". 
sometimiento a las normas del Libro V del Código de Derecho Canónico. En las privadas, la administración y disposición de sus bienes se somete a lo dispuesto en sus Estatutos. Pero, atendiendo a que los estatutos han de ser aprobados por la autoridad eclesiástica y teniendo en cuenta que estas fundaciones privadas están sujetas a la vigilancia del Obispo, como Protectorado de las mismas, se propone que los actos de disposición y enajenación de bienes estén sujetos también a las licencias pertinentes de las autoridades eclesiásticas ${ }^{89}$, y que así conste en sus estatutos.

Sexta.- En la modificación de estatutos, fusión de fundaciones y en la extinción de las mismas, generalmente se establece, y así debe seguir contemplándose en los estatutos, la necesidad de contar con la aprobación de la autoridad eclesiástica que las ha erigido.

Séptima.- En cuanto al destino de los bienes, también con carácter general se dispone (y ésta es la propuesta) que el Patronato quedará constituido en "Comisión liquidadora" y el remanente se entrega a la persona o personas jurídicas que han dado origen a esa fundación autónoma. ${ }^{90}$

\section{R E S U M E N}

El trabajo consta de tres partes: en la primera, tras una introducción, se intentará exponer brevemente la situación de las fundaciones autónomas en las diócesis españolas y en la Conferencia Episcopal española; en la segunda, se expondrán desde la práctica situaciones sobre el régimen jurídico de fundaciones autónomas públicas y privadas, que se están constituyendo en las diócesis españolas y en la Conferencia Episcopal, en las que se observa, por parte de las autoridades eclesiásticas, una falta de criterio a la hora de distinguir entre fundaciones públicas y privadas, al tiempo que se presenta como inevitable la necesidad de un desarrollo de la normativa particular sobre fundaciones autónomas. En la tercera parte, finalmente se esbozarán algunas propuestas que podrían integrar esta normativa particular sobre las fundaciones autónomas.

Palabras clave: fundacion, régimen jurídico, normativa particular.

89 Bien sea la Santa Sede, la Conferencia Episcopal, el Superior del Instituto de Vida Consagrada, o el Obispo.

90 Diócesis, parroquia, instituto de vida consagrada, etc. 


\section{Bibliografía}

Berenguer Beneyto R., Las fundaciones religiosas de la Iglesia Católica. Fundaciones pías autónomas, Madrid 2007.

Berenguer Beneyto R., Tipología de las fundaciones pías autónomas en la diócesis de Valencia, en: R. BENEYTO BERENGUER (Director), Reflexión y perspectivas de futuro de las fundaciones autónomas, Thomson Reuters Aranzadi, Cizur Menor 2013.

Berenguer Beneyto R., "Estatuto jurídico de las obras de la Iglesia como fundación civil", (en:) J. BOSCH, (editor), Cuestiones actuales de derecho canónico y derecho eclesiástico del Estado (Actas de las XXXIV Jornadas de Actualidad Canónica, organizadas por la Asociación Española de Canonistas en Madrid, 23-25 de abril de 2014), Dykinson, Madrid 2015.

Ceballos Herrera E., Hacia la construcción de un Registro fiel reflejo de la realidad. La reforma del Registro de Entidades Religiosas, "Revista General de Derecho Canónico y Eclesiástico del Estado" 2015, nr 39.

Guerín Otaduy J., "Fundaciones canónicas privadas promovidas por Institutos Religiosas en los sectores de la educación y de la sanidad", "Ius canonicum" 2015, nr 55.

Ibáñez Campo M., Las fundaciones canónicas en España. Derecho particular diocesano y realidad social, "Ius Canonicum" 2015, nr 55.

\section{KONFERENCJA EPISKOPATU HISZPANII. \\ CZY ISTNIEJE KONIECZNOŚĆ REGULACJI PARTYKULARNEJ W ODNIESIENIU DO FUNDACJI AUTONOMICZNYCH?}

\section{Streszcze n i e}

Artykuł składa się z trzech części: pierwsza, poprzedzona wstępem, przedstawia zwięźle sytuacje fundacji autonomicznych w diecezjach hiszpańskich i Konferencji Episkopatu Hiszpanii; w części drugiej ukazano sposób postępowania wobec fundacji publicznych i prywatnych powoływanych do życia w diecezjach hiszpańskich i przez Konferencję Episkopatu Hiszpanii, gdzie w konsekwencji zauważamy brak jasnych kryteriów w odróżnianiu fundacji publicznej od prywatnej przez władze kościelne, w momencie uregulowania prawnego o fundacjach autonomicznych. W części trzeciej zostały przedstawione niektóre propozycje umożliwiające integrację przepisów partykularnych w odniesieniu do fundacji autonomicznych.

\section{Słowa kluczowe: fundacja, porządek prawny, norma patrykularna}




\section{EPISCOPAL CONFERENCE OF SPAIN \\ - IS THERE A NEED FOR PARTICULAR REGULATIONS CONCERNING AUTONOMOUS FOUNDATIONS?}

\section{S u m m a r y}

The article is divided into three parts: the first one, preceded by an introduction, succinctly presents the position of autonomous foundations in Spanish dioceses and the Episcopal Conference of Spain; the second part shows the procedure used for public and private foundations created in Spanish dioceses and by the Episcopal Conference of Spain, where as a consequence we can see the lack of clear criteria in differentiating public and private foundations by the Church authorities, in the moment of legal regulating of the autonomous foundations. The third part contains presentations of some of the solutions enabling integration of particular rules concerning autonomous foundations.

Keywords: foundation, legal order, particular norm

\section{ЕПИСКОПСКАЯ КОНФЕРЕНЦИЯ ИСПАНИИ. ЕСТЬ ЯИ НЕОБХОДИМОСТЬ В КОНКРЕТНОЙ РЕГУ ЯЯЦИИ, В ОТНОШЕНИИ К АВТОНОМНОМУ ФОНДУ?}

$$
\text { Р е } з \text { ю м е }
$$

Статья состоит из трех частей: первая представляет основу ситуаций автономных фондов испанских епархии и испанской епископской конференции; во второй части показано, как иметь дело с государственными и частными фондами, созданными в испанских епархий и Конференции епископов Испании, где мы видим отсутствие четких критериев, чтобы отличить государственных от частных фондов церковными властями во время юридического урегулирования автономных фондов. В третьей части представлены некоторые предложения по включению положений в отношении к автономным фондам.

Ключевые слова: фонд, правопорядок, правовая норма 